\title{
ANALISIS PROSES PEMBELAJARAN MATEMATIKA PADA MATERI GARIS DAN SUDUT
}

\author{
Sarah Sri Rahayu \\ SMP YPK 2 Manokwari; sarah.apalem@gmail.com
}

\begin{abstract}
This study aims to find out an overview of how the mathematics learning process on lines and angles in class VII SMP YPK 2 Manokwari, the level of teacher readiness, and to obtain an overview of the implementation of student-centered learning through the contextual learning model that takes place at SMP YPK 2. Manokwari on lines and angles. The method used in this research is descriptive method with a qualitative approach. The results showed that (1) The learning process of mathematics at SMP $Y P K$ 2, especially in the material of lines and angles, has gone well in accordance with the learning plan that has been made and in accordance with the learning steps, namely introduction, core activities, closing, and evaluation (2) The readiness of the teacher in preparing for learning is good (3) The implementation of learning that is centered on students through the contextual learning model has not been fully carried out due to time constraints and differences in the abilities of each student which are not the same as the lack of existing facilities and infrastructure.
\end{abstract}

Keywords: Learning process; lines and angles

\begin{abstract}
ABSTRAK
Penelitian ini bertujuan untuk mengetahui mengetahui gambaran mengenai bagaimana proses pembelajaran matematika pada materi garis dan sudut di kelas VII SMP YPK 2 Manokwari, tingkat kesiapan guru, dan memperoleh gambaran tentang pelaksanaan pembelajaran yang berpusat pada peserta didik melalui model pembelajaran kontekstual yang berlangsung di SMP YPK 2 Manokwari pada materi garis dan sudut. Metode yang digunakan dalam penelitian ini adalah metode deskriptif dengan pendekatam kualitatif. Hasil penelitian menunjukkan bahwa (1) Proses pembelajaran matematika di SMP YPK 2 khususnya pada materi garis dan sudut sudah berjalan dengan baik sesuai dengan perencanaan pembelajaran yang telah dibuat dan sesuai dengan langkah-langkah pembelajaran yaitu pendahuluan, kegiatan inti, penutup, dan evaluasi (2) Kesiapan guru dalam mempersiapkan pembelajaran sudah baik (3) Pelaksanaan pembelajaran yang berpusat pada peserta didik melalui model pembelajaran kontekstual belum sepenuhnya dilakukan karena keterbatasan waktu dan perbedaan kemampuan pada setiap peserta didik yang tidak sama kurangnya sarana dan prasarana yang ada.
\end{abstract}

Kata kunci: Proses pembelajara; garis dan sudut

\section{PENDAHULUAN}

Pendidikan di Negara Indonesia sudah berkembang semakin baik, hal ini terbukti dengan semakin berkembangnya ilmu pengetahuan dan teknologi di segala segi yang membuat bangsa tidak lagi menjadi bangsa yang tertinggal tetapi bangsa Indonesia telah menjadi bangsa yang dapat bersaing dengan bangsa lain. Sebagai anak bangsa terlebih sebagai tenaga pendidik dituntut untuk dapat 
mengikuti segala perkembangan yang ada bahkan dituntut untuk lebih terlibat dalam upaya meningkatkan perkembangan ilmu pengetahuan dan kemajuan jaman dengan cara menciptakan inovasi dalam proses pembelajaran sehingga pembelajaran dapat berlangsung secara baik dan menyenangkan baik oleh guru terlebih oleh para peserta didik. Tidak dapat dipungkiri, bahwa meskipun pendidikan formal dinegara sudah berlangsung sejak lama namun sampai saat ini kondisi pembelajaran yang dilakukan di banyak sekolah di Indonesia masih sangat monoton. Monoton artinya bahwa pembelajaran yang berlangsung hanya terpaku pada metode yang selalu sama dan tidak ada ragamnya. Pembelajaran yang dilakukan sampai saat ini lebih identik dengan kegiatan membaca, menghafal dan mengingat materi pelajaran. Dalam proses kegiatan belajar mengajar, kecenderungan yang terjadi adalah guru lebih mendominasi kegiatan belajar mengajar yang ada karena kegiatan belajar dianggap sebagai proses transfer materi dari guru kepada peserta didik dan peserta didik hanya menerima materi yang disampaikan oleh guru. Keadaan tersebut mengakibatkan proses belajar mengajar menjadi sesuatu yang membosankan dan tidak menyenangkan karena dalam proses tersebut peserta didik tidak terlibat secara aktif di dalamnya.
Berdasarkan kenyataan tersebut, untuk dapat menciptakan suasana belajar yang menyenangkan dan tidak lagi membosankan, maka haruslah diciptakan pola pembelajaran yang baru yang melibatkan peserta didik turut berperan secara aktif di dalamnya. Proses pembelajaran tidak hanya sekedar membaca, menghafal, dan mengingat, tetapi lebih dari itu peserta didik di tuntut untuk lebih jeli dalam menemukan sesuatu yang berguna bagi kehidupannya bahkan mampu memecahkan masalah yang ditemukan dalam kehidupannya sehari-hari dengan konsep pengetahuan yang sudah dipelajarinya.

Keberadaan peserta didik di setiap lembaga pendidikan berasal dari latar belakang yang berbeda-beda. Hal ini akan berpengaruh pada gaya belajar dari setiap peserta didik. Oleh karena itu guru di tuntut untuk lebih peka dalam memahami perbedaan yang ada diantara peserta didiknya dengan cara mampu menganalisis gaya belajar dari setiap peserta didik sehingga dapat tercipta pembelajaran yang bermakna. Evaluasi diri juga perlu dilakukan oleh guru agar dapat mengetahui sejauh mana keberhasilan proses belajar mengajar yang sudah dilakukan, dengan demikian guru dapat memperbaiki segala kekurangan-kekurangan yang ada agar dapat mencapai tujuan pembelajaran yang diharapkan. 
Selain pembelajaran yang berpusat pada peserta didik, perlu juga dikembangkan pembelajaran kontekstual (Depdiknas, 2007:25). Pembelajaran kontekstual adalah pembelajaran yang dimulai dengan mengambil (mensimulasikan, menceritakan) kejadian pada dunia nyata kehidupan sehari-hari yang dialami peserta didik kemudian dikaitkan dengan konsep matematika yang dibahas (Hidayati, 2009). Pembelajaran kontekstual berlangsung berdasarkan pengalaman pribadi peserta didik yang dihubungkan dengan materi pelajaran yang sedang dipelajari yang kemudian dibahas dalam bentuk diskusi dan tanya jawab. Pembelajaran kontekstual dilakukan dengan proses merinci secara sistematik semua urutan perilaku peserta didik dan guru yang berlangsung dalam proses pembelajaran.

Materi garis dan sudut merupakan salah satu materi yang pelajari oleh peserta didik di kelas VII. Materi ini mengajarkan kepada peserta didik selain mampu untuk membedakan kedudukan dua garis tetapi juga peserta didik mampu untuk menggambar dan mengukur besar sudut dengan menggunakan busur derajat. Hal ini dianggap penting karena pada materi inilah peserta didik dikenalkan dengan penggunaan busur derajat sebagai alat dalam melukis dan mengukur sudut.

Dalam proses pembelajaran, penggunaan metode pendekatan pembelajaran sangat menentukan keberhasilan tujuan yang akan dicapai. Penggunaan pendekatan pembelajaran yang tidak tepat akan mengakibatkan belum tercapainya semua tujuan tersebut.

\section{METODE PENELITIAN}

Penelitian ini dilaksanakan di kelas VII pada SMP YPK 2 Manokwari semester genap, tahun ajaran 2018/2019. Dalam pelaksanaan penelitian ini. Peneliti diharuskan hadir di lokasi penelitian karena peneliti merupakan instrument utama dalam proses pengumpulan data dan pengumpulan data yang dilakukan harus dalam situasi yang sebenarnya. Instrumen utama berarti peneliti sebagai perencana, pelaksana, pengendali, pengumpul dan penganalisis data, penarik kesimpulan dan pembuatan laporan.

Penelitian ini merupakan penelitian kualitatif yaitu peneliti sebagai instrumen utama, menggunakan metode kualitatif (Penelitian ini dilakukan dalam situasi yang wajar dan mengutamakan data yang bersifat kualitatif), mempunyai latar alami, bersifat deskriptif (Penelitian ini merupakan upaya untuk mendeskripsikan permasalahan yang terkait dengan proses pembelajaran matematika di SMP YPK 2 Manokwari), analisis data secara induktif, artinya peneliti berusaha mendeskripsikan permasalahan berdasar data yang terbuka bagi penelitian lebih lanjut,dan lebih mementingkan proses daripada hasil. Oleh 
karena itu pendekatan penelitian ini adalah pendekatan kualitatif.

Ada empat sumber data dalam penelitian ini, yaitu informan kunci (keyinforman), informan tambahan, tempat dan peristiwa, serta dokumen.

\section{HASIL DAN PEMBAHASAN}

Analisis Proses Pembelajaran

Matematika Pada Materi Garis Dan

Sudut Kelas VII Pada SMP YPK 2

Manokwari.

Proses pembelajaran matematika yang berlangsung di SMP YPK 2 Manokwari meliputi tahapan perencanaan pembelajaran, pelaksanaan pembelajaran, serta evaluasi dan tindak lanjut.

a. Perencanaan Pembelajaran

Berdasarkan instrument penilaian yang diisi oleh wakasek kurikulum pada SMP YPK 2 Manokwari diperoleh data :

(1) Sebelum pembelajaran dimulai, guru matematika menyampaikan tujuan umum dari proses pembelajaran yang akan berlangsung.

(2) Metode pembelajaran yang digunakan dalam menyampaikan materi garis dan sudut adalah metode pemberian tugas, diskusi kelompok, dan pemecahan masalah.

b. Pelaksanaan Pembelajaran

Dalam pelaksanaan pembelajaran matematika, baik di SMP YPK 2 Manokwari melalui tiga tahapan kegiatan, yaitu tahapan prainstruksional (pendahuluan/kegiatan awal), tahapan instruksional (kegiatan inti), dan tahapan penutup. Penyajian data penilaian pelaksanaan pembelajaran yang di tampilkan pada gambar 1 sebagai berikut:

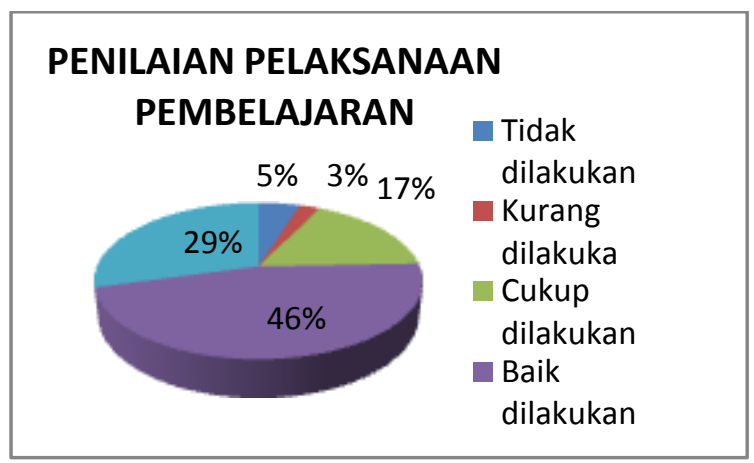

Gambar 1: Penilaian Pelaksanaan Pembelajaran

Berdasarkan Gambar 1 menunjukan bahwa pada pelaksanaan pembelajaran hanya $46 \%$ dilakukan dengan baik dan $29 \%$ tidak dapat dilakukan dengan baik. Pembelajaran berpusat pada peserta didik (Student Centered Learning)

Menurut wakil Kepala Sekolah dan hasil wawancara dengan guru kelas VII SMP YPK 2 Manokwari bahwa:

(a) Selama proses pembelajaran berlangsung guru memberikan kesempatan seluas-luasnya kepada peserta didik untuk berperan aktif dalam proses pembelajaran matematika.

(b) Dalam penyelesaian tugas, peserta didik di minta untuk berani menampilkan jawabannya di papan tulis 
(c) Dalam penyelesaian soal/tugas, guru meminta peserta didik untuk membantu peserta didik yang belum memahami (tutor sebaya).

Persentase minat belajar peserta didik dalam pembelajaran garis dan sudut disajikan pada gambar 2 berikut ini:

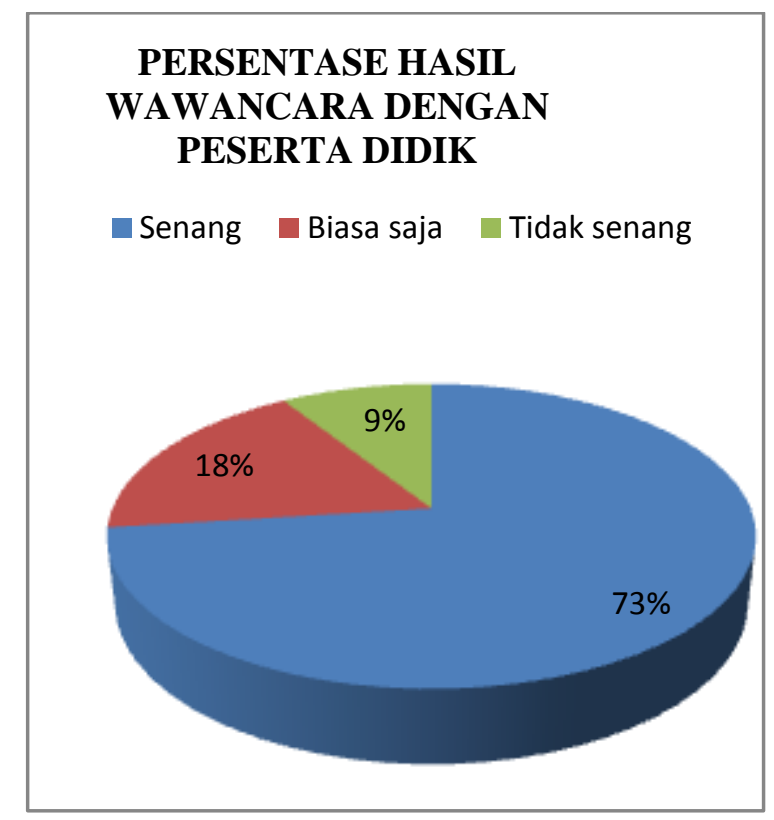

Gambar 2: Persentase hasil wawancara dengan peserta didik

Berdasarkan Gambar 2 menunjukkan

bahwa: Sebanyak $73 \%$ peserta didik senang belajar matematika pada materi garis dan sudut, namun ada yang 15\% biasa saja dan 9\% tidak senang. Hal tersebut terjadi karena:

1. Pelaksanaan pembelajaran matematika dalam materi Garis dan Sudut di SMP YPK 2 melalui dua tahapan kegiatan, yaitu:
a. Tahapan
prainstruksional (pendahuluan/kegiatan awal).
b. Tahapan instruksional kegiatan inti).

2. Tahapan penilaian

Dalam tahapan penilaian, penilaian Authentic Assesment belum sepenuhnya dilakukan karena terbatasan waktu dan banyaknya materi. Penilaian Aunthentic Assement merupakan penilaian yang digunakan untuk mengukur kemampuan dan keterampilan peserta didik, biasanya ada suatu produk yang dihasilkan berkaitan dengan materi yang diajarkan dan sesuai dengan konteks dunia nyata.

3. Dalam tahap evaluasi dan tindak lanjut Kegiatan yang dilakukan dalam tahap evalusi adalah melalui pemberian tugas/latihan yang harus dikerjakan oleh peserta didik yang berkaitan dengan materi yang sudah diajarkan. Tugas yang diberikan sekaligus sebagai bahan remedi dan pengayaan.

Hal ini sesuai dengan faktorfaktor yang mempengaruhi hasil belajar oleh Slamanto (2003)

4. Penyusunan Rencana Pelaksanaan Pembelajaran (RPP) yang dilakukan di SMP YPK 2 Manokwari dilakukan oleh masing-masing guru mata pelajaran.

5. Pembelajaran berpusat pada peserta didik dengan model pembelajaran kontekstual belum sepenuhnya dapat dilaksanakan karena keterbatan waktu dan adanya perbedaan kemampuan peserta didik. 
Hal ini sejalan dengan penelitian dari Selmi Yohana Stefani dan Tiurlina Siregar (2014) bahwa minat dapat mempengaruhi hasil belajar.

\section{SIMPULAN DAN SARAN}

\section{SIMPULAN}

Proses pembelajaran matematika pada garis dan sudut kelas VII pada SMP YPK 2 Manokwari berjalan dengan baik sesuai dengan langkah - langkah pembelajaran.

\section{SARAN}

Peserta didik harus dilibatkan secara aktif dalam proses pembelajaran agar pembelajaran yang berpusat pada peserta didik (Student Centered Learning) dengan model pembelajaran kontekstual dapat terlaksana dengan baik.

\section{UCAPAN TERIMAKASIH}

Kepada Kepala Sekolah SMP YPK 2 Manokwari yang telah memberi dukungan dalam penelitian ini.

\section{DAFTAR PUSTAKA}

Depdiknas, 2007, Naskah Akademik Pendidikan Keterampilan, Jakarta:Depdiknas;

Slameto, (2003), Belajar dan Faktor-faktor yang mempengaruhinya, Jakarta: Rineka Cipta;

Selmi Yohana Stefanie dan Tiurlina Siregar, 2014, Perbedaan minat dengan hasil belajar kimia dengan menggunakan model pembelajaran kooperatif tipe jigsaw di SMA Negeri 1 Sentani, Jurnal Ilmu Pendidikan Indonesia, 2 (2), 54 - 63;

Yulia Maftuhah Hidayati, 2009, Analisis Proses Pembelajaran Matematika Di SMA Negeri Surakarta (Penelitian Dilaksanakan Di Kelas X SMA Negeri 1 Dan SMA Negeri 4 Surakarta), Universitas Sebelas Maret. Surakar. 